\title{
Do Multinationals Make GDP Obsolete?
}

\author{
François Lequiller* \\ Paris (France)
}

Multinationals play an increasingly important role in the world economy. Their fiscal optimization leads to bias macroeconomic statistics. This was ignored by statisticians until the Irish CSO published an extraordinary $+27 \%$ growth number for 2015. This originates most probably from a simple administrative reallocation in Dublin of the intellectual property products of a big American multinational. As royalties are classified as production in national accounts and exports are registered not from where they are physically shipped but from the country that holds their property rights, GDP was massively impacted.

Many economists were thunderstruck. Some concluded that a «national» GDP is now obsolete. Some that only its income approach remains relevant. In this article, the author strongly advocates that a national GDP in volume remains an essential tool for economic policy and that, if necessary, statisticians should reconsider the rules of the SNA 2008, whether to classify royalties as production or to extrapolate the goods for processing concept, in order to recover a sensible measure of growth.

Keywords: system of national accounts, GDP, approaches to GDP calculation, globalisation, multinationals, intellectual property products, royalty, goods for processing.

JEL: E01, F23, O47.

doi: https://doi.org/10.34023/2313-6383-2019-26-9-53-57.

For citation: Lequiller F. Do Multinationals Make GDP Obsolete? Voprosy Statistiki. 2019;26(9):53-57. (In English)

\section{Устаревает ли показатель ВВП в условиях глобализации экономики?}

\author{
Франсуа Лекийе* \\ г. Париж (Франция)
}

Транснациональные корпорации играют все более важную роль в мировой экономике. Проводимая ими фискальная оптимизация порождает смещенные оценки в макроэкономической статистике. Данный факт статистики игнорировали, пока Центральное статистическое управление Ирландии не опубликовало экстраординарную оценку индекса экономического роста за 2015 г.: $+27 \%$. Скорее всего, это происходит из-за простого административного решения - переноса продуктов интеллектуальной собственности крупной американской многонациональной корпорации в Дублин. Поскольку роялти в национальных счетах классифицируются как производство, а экспорт регистрируется не там, где продукты физически отгружаются, а в стране, которая обладает правами собственности на них, это в значительной мере повлияло на ВВП.

Многие экономисты были ошеломлены. Некоторые пришли к выводу, что показатель «национальный ВВП» в настоящее время устарел. Другие - что релевантным можно считать только метод его расчета по доходам. Автор же этой статьи решительно выступает за то, чтобы национальный ВВП, измеряемый в постоянных ценах, оставался важным инструментом экономической политики, а при необходимости, для того чтобы восстановить его в качестве разумной меры роста, статистики должны

* François Lequiller has made his main career at INSEE, the French statistical office, where he was head of consumer prices and national accounts. His large international experience includes working as expert in national accounts in the IMF (1993-1995), as head of National Accounts in the OECD (2001-2007), and as head of Government Finance Statistics in Eurostat (2010-2014). Being one of 2008 SNA developers, he is the main author of «Understanding National Accounts», a manual published by the OECD.

* Франсуа Лекийе значительную часть профессиональной деятельности осуществлял в INSEE, статистической службе Франции, возглавляя отделы потребительских цен и национальных счетов. Его широкий международный опыт включает работу эксперта по национальным счетам в МВФ (1993-1995), руководителя отдела национальных счетов в ОЭСР (2001-2007), руководителя отдела статистики государственных финансов в Евростате (2010-2014). Будучи одним из разработчиков СНС-2008, он является основным автором руководства ОЭСР «Понимание национальных счетов». 
пересмотреть правила СНС-2008: идет ли речь о классификации роялти как производства или об экстраполяции концепции «товары для переработки».

Ключевые слова: система национальных счетов, ВВП, методы исчисления ВВП, глобализация, многонациональные корпорации, продукты интеллектуальной собственности, роялти, товары для переработки.

JEL: E01, F23, O47.

doi: https://doi.org/10.34023/2313-6383-2019-26-9-53-57.

Для цитирования: Лекийе Ф. Устаревает ли показатель ВВП в условиях глобализации экономики? Вопросы статистики. 2019;26(9):53-57. (На английском языке)

Many, like me, are dazzled by the innovative products and the efficiency of the services offered by the GAFA... while being offended by their tax optimisation, which is quite legal in fact! But few know that their behaviour has an impact on the quality of macroeconomic statistics. Indeed, tax optimisation by multinationals plays on three levels: (1) transfer prices between subsidiaries, (2) artificial location of their intangible assets, (3) creation of «empty shell» companies which unique role is to transfer profits to tax havens. The first level directly affects GDP, which only makes sense if the transactions included in it are valued at market price. The second, based on the extreme ubiquity of these intangible assets (software, patents, licenses), creates value added where it is least taxed and not where it is generated. The third creates fictitious interest flows between countries and skews direct investment statistics.

Statisticians have long been aware of these problems, but, being powerless to correct them (their access to the strategic data of these companies is minimal), they ignored them in practice... until the statistical earthquake of July 2016 when it was announced by the Central Statistical Office (CSO) of Ireland that the country's growth of 2015 (i. e. GDP in volume) had been revised to $+26 \%$ from $+7 \%$ ! This prompted Paul Krugman, Nobel laureate in economics and columnist at The New York Times, to tweet the next day: «Leprechaun economics? Why are these in GDP?». Knowing that «Leprechauns» are little elves of the Celtic mythology, this reflected the stupor of most commentators in front of a figure that may seem aberrant knowing that neither employment nor consumption of households followed. Krugman's wording was a bit nasty because the CSO is a very professional statistical institute which is faced with a situation that is out of the ordinary: huge multinationals and a small country...

The exact origin of this $+27 \%$ remains still unclear, and that is why I will use the conditional in this paper. This restraint is in fact to the credit of our Irish colleagues [1]. Indeed, the problem stems from one (or a few, it is not clear) company(ies) while, as in all countries, the CSO has the obligation to preserve the confidentiality of individual company accounts. Everyone guessed, however, that the main company responsible for this figure is one of the GAFAs, which are well known for worshipping the Irish climate... A precise name circulates under the counter, but I will respect the secret. In fact, it does not matter which of these multinationals is involved because the issue is global: is it still possible today to calculate a GDP, a «territorial» indicator by construction, in a globalized economy where multinationals play an increasingly important role [2]?

Some conclude from the Irish example that the interpretation of GDP (i. e., in volume) as an indicator of activity is to be placed on the shelf of antiquities and that, in our globalized economies, one is condemned to conceive GDP (i. e., in current prices) only as an indicator of income [3]. In the present article, I risk continuing to defend GDP (i. e. in volume) as an indicator of activity!

\section{The three approaches to GDP}

National accountants systematically refer to «the three approaches to GDP»: the «output» approach (sum of value added), the «demand» approach (sum of final demand) and the «income» approach (sum of compensation of employees and profits). The conceptual equality (and, often, the numerical equality) of these three approaches is a kind of basic postulate of national accounts. However, one should not forget that the income approach to GDP is incomplete because it corresponds strictly to income from domestic production. In fact, there is income from domestic production which is transferred abroad (for example, wages paid to seasonal non-resident workers) and income from foreign production which is added to the income of domestic households (for example, in the 
case of France, the wages of the French employees of Luxembourgish banks). The concept of GNI, gross national income, has been created to take account of these net income flows with the rest of the world. The GNI is less well known than GDP but is more appropriate when comparing incomes (i.e. per capita) ${ }^{1}$. It is rightly this concept that is used for the calculation of the burden-sharing of the European budget between the Member States and not the concept of GDP2.

For me, while GNI is appropriate for income, GDP, in its so-called «volume» version, which economists often refer to as «real GDP», is and must remain the essential tool for measuring the change in a country's (or a region's) overall output. The concept of «production» (or «output») is specific to economists and is foreign to business accountants. It is based on the famous equation:

$$
Y=f(K, L) \times p m f,
$$

where $Y$ is value added (the sum of which is GDP), $f$ - the «production function», $K$ - capital, $L$ - labour, and $p m f$ - the «multi-factor productivity».

It is true that, for a very long time, national accountants (but not regional accountants) did not really ask themselves where this added value was generated. Their vision of the economy was inspired by an outdated image of workers working on machines in a factory. Value added was therefore, by definition, where the workers and/or the factories and machines were.

\section{Intangible capital is a problem}

But today's economy is increasingly based on «intangible» capital: software, patents, research and development. Aware of this fundamental development, national accountants have integrated these «intangible machines» into the famous «K», that is, into capital. Indeed, the main innovation of the latest version of the global system of national accounts (SNA 2008) has been what is called «capitalization of research and development expenditures». This bold innovation (business accountants are very reluctant to account for
$\mathrm{R} \& \mathrm{D}$ in capital expenditure... ${ }^{3}$ ) led to a general rise in the level of GDP, from 2 to $4 \%$ depending on the country, when it was introduced a few years ago. In this economy measured by national accountants, the monetary flows generated by this new type of capital are «production». Thus, for example, royalties generated by patents or software are assimilated to production and are therefore included in GDP.

The problem that the Irish case has brought to the forefront is that these assets are inherently «transferable» anywhere and often with a single click of a mouse. To put it bluntly, multinationals will legally declare them where they want them to be, this is where the profits they generate will be the least exposed to tax. The basic assumption as to the origin of this extraordinary $+26 \%$ is therefore that, on one fine day of 2015 , a lawyer from a multinational entered the offices of the Commercial Registry in Dublin and declared that his company's patents/software/licenses were now legally owned by its Irish subsidiary. This is confirmed by a spectacular increase in the country's productive assets as measured by the CSO: $+40 \%$ increase in the capital stock! Since the flow of royalties received from its foreign subsidiaries is now officially the property of this subsidiary, its production was thus, by a magic wand, multiplied by a huge factor.

\section{Virtual work}

This does not close the issue. Indeed, an increase in the GDP «production approach» must necessarily translate into an increase in the GDP «demand approach», because of the basic equality mentioned above. This overall coherence has been respected by the CSO through a dramatic increase in merchandise exports, from $€ 114.5$ billion to $€ 200.3$ billion, as shown in the table below, almost doubling exports (an absolute record for an OECD country). If you are wondering how Irish shipping or air carriers have managed this explosion, you are on the wrong track because this increase is immaterial. It comes largely from a special line with an strange wording: «goods for processing».

\footnotetext{
${ }^{1}$ It is, however, in my view, incomplete from a strict income point of view because it ignores capital gains (or losses) which are excluded in principle from the concept of production in the national accounts. This was a shock to Alan Greenspan when he realized that the national accounts subtracted taxes on capital gains from household income without not adding the taxable base, that is, the capital gains themselves!

${ }^{2}$ Ireland benefits greatly from this because its GNI is significantly lower than its GDP.

${ }^{3}$ IAS 38.54 recommends «allocation of all research costs to expenses». IAS 38.57 recommends that «development costs are capitalized only after the technical and commercial feasibility of the asset to be sold or used has been determined. This means that the enterprise must have the intention and be able to complete the intangible asset and use or sell it and be able to demonstrate how the asset will generate future economic benefits. If an enterprise cannot distinguish the research phase of an internal project to create an intangible asset from the development phase, it will treat the expenses for that project as if they had been incurred in the research phase only».
} 
Table

Ireland, International merchandise trade, EUR billions

\begin{tabular}{|l|c|c|c|c|c|}
\hline & 2012 & 2013 & 2014 & 2015 & 2016 \\
\hline $\begin{array}{l}\text { International trade (customs } \\
\text { concepts) }\end{array}$ & & & & & \\
\hline Exports & 93,5 & 89,2 & 92,6 & 112,4 & 117,6 \\
\hline \multicolumn{1}{|c|}{ Imports } & 56,2 & 55,8 & 62,1 & 70,1 & 72,1 \\
\hline Goods for processing & & & & & \\
\hline Exports & 6,1 & 7,1 & $\mathbf{1 8 , 6}$ & $\mathbf{7 8 , 6}$ & 67,6 \\
\hline Imports & 6,9 & 7,2 & 10,2 & 13,6 & 11,6 \\
\hline Other adjustments (net) & $-0,4$ & $-1,2$ & $-1,9$ & $-6,1$ & $-4,4$ \\
\hline Total merchandise exports & 101,9 & 98,7 & $\mathbf{1 1 4 , 5}$ & $\mathbf{2 0 0 , 3}$ & 194,1 \\
\hline Total merchandise imports & 65,0 & 64,2 & 73,7 & 86,9 & 88,2 \\
\hline Nominal GDP & 175,2 & 179,9 & $\mathbf{1 9 5 , 3}$ & $\mathbf{2 6 2 , 5}$ & 273,2 \\
\hline
\end{tabular}

Source: CSO.

«Processing» in its basic form consists for a company to have an operation done outside (of the country, in our context) on one of its products and to reimport it. In this context, it seems advisable for statisticians to avoid including in export figures the value of the gross product sent abroad, as well as, in the import figures, the value of the processed product repatriated. Only the cost of the service performed by the foreign operator should be recorded as an importation, as «goods for processing». This type of operation is quite common, for example, in the oil or aircraft industries. Accounting for it in this way avoids double counting in the flows of exports and imports the value of these petroleum or aircraft products, while not affecting the balance of exports/imports.

The massive increase in this item in 2015 for Ireland comes from a more systematic interpretation of this concept that applies, since the SNA 2008, even if the processed product does not return to the country of origin [4]. The difference with our above basic processing is that if the unit which owns the goods in a country $A$ has had its product assembled in a country $B$ from which the products are directly distributed throughout the world (without being repatriated to $A$ ), these will be counted as exports of $A$ even if, physically, they are exported by $B$. This is a case where the national accounts (and balance of payments) statistics differ from the customs statistics which continue to be calculated on the base of physical flows.

\section{A simple example}

Take the example of a multinational that would produce smartphones ${ }^{4}$. Let us imagine that its organization is as follows: the head company is in Ireland, the design is made in California, the elements (property of the head) are manufactured in several countries and are assembled in China from where the final product (property of the head) is sent all over the world to be sold. In a traditional view of exports, China exports these smartphones. In the design of the SNA recommendations, as the components and the final product remain the property of the parent company, smartphones are not exported by China (even if they are physically exported by this country) but by their «economic owner», established in Ireland. So, the real exporter of smartphones is Ireland. This is where the $€ 78.6$ billion in exports in 2015 (followed by $€ 67.6$ billion in 2016) of «goods for processing» by Ireland would come from. It should be noted that the amount of these «exports» is probably not «invented» by statisticians: the accounts of the head company will actually show these invoices. Since production in the national accounts is measured in practice by sales (plus changes in stocks of finished products), it seems logical that production should increase in line with exports. The company's accounts also most likely show the cost of the Chinese subsidiary's assembly work and, in one form or another, the cost of the development of the design in California. These two flows are treated as imports of services in intermediate consumption, which are subtracted from production to arrive at Value Added, which composes GDP. But, as can be seen from the table above, there is no dramatic increase in imports of goods for processing. On the other hand, but this does not appear in the table which covers only «goods», there is indeed a significant increase in imports of «Royalties» and R\&D services of around $€ 30$ billion. This does not, however, compensate for the explosion in exports of goods for processing. Should this be attributed to an underestimation by the company of these flows, which would have the effect of inflating the profits located in Ireland?

In any case, the basic problem stems from the extraordinary gift of ubiquity of these property rights. What specifically happened in 2015 to bring about this extraordinary rise in GDP? Probably, as mentioned above, the mere fact that a lawyer has stated that these rights are based in Ireland. This is where the question of the significance of GDP growth arises: how can a simple administrative declaration lead to such growth? Moreover, it is easy to assume that there is necessarily another country where there should be a symmetric decline in GDP. But the mystery thickens because no statistician knows where these property rights were previously declared ${ }^{5}[5]$. We are now faced with a very bad taste in our mouths: what does GDP in volume mean in this context?

\footnotetext{
${ }^{4}$ Let us be clear: this is just one example, perhaps not the speciality of the multinational in question in Ireland....

${ }^{5}$ A rumor circulates that this was in Jersey (which GDP is not part of the UK'S GDP). But it must be a rumor because Jersey itself publishes a GDP that does not fall in 2015 ...
} 


\section{What are the solutions?}

Some economists conclude that the interpretation of GDP as an indicator of activity is doomed and that it should be interpreted only as an indicator of income [6]. Indeed, from an income point of view, the $+32 \%$ of Irish GDP at current prices in 2015 is quite understandable: it is undeniable that billions of euros and/or dollars of income have suddenly started to be transferred into Dublin as soon as the rights have been registered there.

My conclusion is significantly different. It is triple. First, at the risk of sounding old-fashioned, I still believe that there is room for a global indicator of activity to measure growth and that this indicator must continue to be called and calculated as the traditional volume of GDP. Secondly, in order to calculate a meaningful growth from this indicator, it is necessary to use some common sense: the flows related to royalties and/or property rights are financial flows and not «production». Thirdly, the Irish unit that claims to own the rights to the intangible assets of the multinational does not «produce» smartphones! It «produces» the financial and management services of the multinational. The design of smartphones is «produced» in the Silicon Valley and the physical smartphones are «produced» in China.

If, in order to do this, we must reconsider in the 2008 SNA the recommendation of capitalising R\&D and/or generalising the implementation in a «virtual» way of goods for processing, so much the worse! As we saw when the new system was introduced, these changes affected only the level of GDP, almost not its variation. And growth is not a concept in terms of levels but of variations'. Finally, I believe that the 'income approach' should be linked to GNI and not to GDP. Why not use the former as the denominator of deficit and debt ratios rather than GDP? The GNI is probably a better indicator of the taxable base than GDP 8 ! Thus, by reclassifying, as common sense requires, the income flows transferred to Ireland as financial income, and not production, GNI will be increased, which is quite understandable, while avoiding to impact GDP.

Some economists go even further as to say that, in our globalized economies, calculating a «national» GDP is stupid and that we are condemned to calculating a «global GDP» [7]. My answer is categorical: it would be a serious failure for statisticians to abandon calculating a national GDP because it is an essential tool for economic policy. There is no world government; even in Europe, economic policy is not done in Brussels. It remains decided by national governments. We must therefore preserve this fundamental tool for the conduct of our advanced economies. The problem is that a GDP that grows by $26 \%$ with no impact on employment is of no use to the Irish government. We must therefore give ourselves the means to recover its meaningfulness.

\section{References}

1. Connolly M. Global Production and Economic Globalization - an Irish Perspective. CSO Ireland; 2017.

2. Schreyer P. Globalisation, Intellectual Property Products and Measurement of GDP: Issues and Proposals. CSSP Informal Reflection Group. In: 15th Meeting of the Committee on Statistics and Statistical Policy, 20-21 June 2018, Geneva, Palais des Nations.

3. Blanchet D. et al. La Croissance Est-Elle SousEstimée? In: L'Economie Française. Comptes et Dossiers. Édition 2018. Rapport sur les Comptes de la Nation 2017. Insee; 2018.

4. Khder M-B., Ragache N. La Croissance 2014-2015 du PIB Irlandais: Quelle Interprétations, Quelle Conséquences? Economie et Statistique. Due for publication in 2020.

5. Stapel-Weber S., Verrinder J. Globalisation at Work in Statistics - Questions Arising From the «Irish Case». EURONA - Eurostat Review on National Accounts and Macroeconomic Indicator. 2016;2.

6. CSO Ireland. Report of the Economic Statistics Review Group (ESRG). December 2016.

7. Moulton B., Van de Ven P. Addressing the Challenge of Globalization in National Accounts. In : The Challenges of Globalization in the Measurement of National Accounts. NBER; 2018.

\section{About the author}

François Lequiller - expert in national accounts, Paris. E-mail: francois.lequiller@orange.fr.

\section{Информация об авторе}

Лекийе Франсуа - эксперт в области национальных счетов, Париж. E-mail: francois.lequiller@orange.fr.

\footnotetext{
${ }^{6} 32 \%$ at current prices, $26 \%$ at constant prices.

${ }^{7}$ National accounts experts perfectly know that the «level» of real GDP is arbitrary. In fact, real GDP is calculated as a series of growth rates.
}

${ }^{8}$ GNI might be even better as a taxable base if capital gains or losses were added. 